\title{
ANALISIS KORELASI KERAPATAN TITIK API DENGAN CURAH HUJAN DI PULAU SUMATERA DAN KALIMANTAN
}

\author{
Correlational Analysis between Hotspots Density and Rainfall \\ in Sumatera and Kalimantan
}

\author{
M. Bayu Rizky Prayoga ${ }^{1)^{\star}}$, Ardila Yananto ${ }^{2)}$ dan Della Ananto Kusumo ${ }^{3)}$ \\ ${ }^{1,2)}$ Balai Besar Teknologi Modifikasi Cuaca - Badan Pengkajian dan Penerapan Teknologi, Gedung Ir. \\ Mohammad Soebagio, GEOSTECH (820), Kawasan PUSPIPTEK, Serpong, Tangerang Selatan \\ ${ }^{3)}$ Badan Informasi Geospasial (BIG), Jalan Raya Bogor Km. 46, Cibinong, Bogor \\ ${ }^{*}$ E-mail : bayu.rizky@bppt.go.id
}

\begin{abstract}
Intisari
Kebakaran hutan dan lahan merupakan bencana yang rutin terjadi di Indonesia. Pulau Sumatera dan Kalimantan menjadi wilayah yang paling sering dilanda kebakaran hutan dan lahan. Munculnya titik api di wilayah Sumatera dan Kalimantan mempunyai pola tersendiri. Penelitian ini bertujuan untuk mengetahui secara spasial-temporal konsentrasi titik api di wilayah Sumatera dan Kalimantan serta korelasinya dengan curah hujan. Berdasarkan hasil pengolahan data titik api yang bersumber dari hasil perekaman citra MODIS (Satelit Terra \& Aqua) tahun 2006-2015, didapatkan bahwa kerapatan titik api di Pulau Sumatera dan Kalimantan akan mencapai puncaknya pada bulan September. Wilayah yang memiliki konsentrasi titik api paling tinggi adalah Provinsi Riau dan Sumatera Selatan di Pulau Sumatera serta Provinsi Kalimantan Tengah dan Kalimantan Barat di Pulau Kalimantan. Hasil pengolahan data curah hujan bulanan juga menunjukkan bahwa pada bulan September curah hujan di Pulau Sumatera dan Kalimantan mencapai nilai terendah dalam satu tahun, yaitu 25-150 mm/bulan. Selain itu, korelasi antara jumlah titik api dan curah hujan menunjukkan nilai korelasi yang cukup $(R=0,307)$ dengan pola hubungan yang negatif. Hasil pengolahan terhadap data historis titik api ini bisa menjadi acuan dalam kesiapan penanggulangan bencana kebakaran hutan dan lahan yang sering terjadi di Pulau Sumatera dan Kalimantan.
\end{abstract}

Kata Kunci : Kebakaran Hutan, Kerapatan Titik Api, Sumatera, Kalimantan, Curah Hujan.

\begin{abstract}
Forest fire is one of disasters that occur regularly in Indonesia. Sumatera and Borneo are regions with the most frequently hit by forest fires disaster through years. The emergence of hotspots in Sumatera and Borneo have it own patterns. This study aimed to figure hotspot density in Sumatera and Borneo spatial-temporally and their correlation with rainfall. Based on the results of data processing hotspots sourced from recording of MODIS satellite (Terra and Aqua) 2006-2015, it was found that the density of hotspots in Sumatra and Kalimantan will reach its peak in September. Riau and South Sumatera Province are the regions that has highest concentration of hotspots in Sumatera island, meanwhile Central Borneo and West Borneo Province become the regions that has highest concentration of hotspots in Borneo island. The processing of monthly rainfall data also shown that in September rainfall in Sumatra and Kalimantan reach its lowest level in a year, which is $25-150 \mathrm{~mm} /$ month. In addition, hotspot density and rainfall are correlated enough $(R=0,307$ ). The results of the processing of historical hotspots data in this paper could become a reference for forest fires disaster management that often happens in Sumatera and Borneo.
\end{abstract}

Keywords : Forest Fires, Hotspots Density, Sumatra, Borneo, Rain.

\section{PENDAHULUAN}

Kebakaran hutan merupakan fenomena yang sering terjadi di Indonesia (Gellert, 1998) yang menjadi perhatian lokal dan global (Herawati \& Santoso, 2011). Kebakaran hutan bukanlah hal yang baru, di Kalimantan kebakaran hutan sudah terjadi sejak abad ke-17 (Levine,
1999; Barber \& Schweithelm, 2000; Page et al., 2002).

Selain kerugian ekonomi, dampak kebakaran hutan dan lahan yang menonjol adalah terjadinya kabut asap yang menganggu kesehatan dan sistem transpotasi darat, laut dan udara. Dampak kebakaran hutan terhadap produksi pertanian diduga tidak terlalu besar 
karena pembakaran dilakukan untuk penyiapan lahan, kecuali jika kebakaran mencapai lahan pertanian yang berproduksi. Kebakaran hutan menghasilkan emisi karbon yang dilepaskan ke atmosfer (Cahyono et al., 2015).

Karakteristik kebakaran hutan di Asia Tenggara sangat terkait dengan status lahan gambut dan status pengelolaan lahan. Hal ini yang menyebabkan variasi aktivitas kebakaran yang tinggi di wilayah ini setiap tahunnya dalam rentang waktu yang lebih lama (Miettinen et al, 2011).

Ada dua faktor penting penyebab kebakaran hutan, yaitu faktor alami dan faktor manusia. Faktor alami misalnya adalah musim kering yang ekstrim yang disebabkan oleh dampak El Nino, sedangkan faktor manusia meliputi penggunaan api dalam persiapan lahan, adanya kekecewaan terhadap pengelolaan hutan, illegal logging, kebutuhan untuk makanan ternak, perambahan hutan, dan sebab-sebab lain (Chokkalingam et al., 2007; Rasyid, 2014; Albar et al., 2016).

Pada saat musim kemarau, pertumbuhan jumlah titik api di wilayah Sumatera dan Kalimantan akan meningkat secara signifikan. Hampir setiap tahun, titik api selalu muncul di Sumatera dan Kalimantan, terutama di lahan gambut yang konsentrasi titik apinya paling banyak. Hal ini tentu saja menjadi perhatian khusus untuk wilayah tersebut terutama pada saat memasuki puncak musim kemarau.

Dalam beberapa tahun terakhir, kebakaran di Pulau Sumatera dan Kalimantan sering terjadi di wilayah dengan tutupan lahan gambut. Pada Pulau Sumatera, wilayah tersebut dominan berada di daerah pesisir Timur Pulau Sumatera seperti Provinsi Sumatera Selatan, Jambi, dan Riau. Sementara di Pulau Kalimantan, wilayah yang sering terjadi kebakaran hutan dan lahan berada di pesisir Barat dan Selatan, tak jarang pula kebakaran hutan dan lahan terkonsentrasi di bagian Tengah Pulau Kalimantan. Kemunculan titik api di wilayah Pulau Sumatera dan Kalimantan secara historis akan mulai pada akhir musim hujan, hingga mencapai puncaknya pada musim kemarau (Juli-Agustus-September).

Penyajian secara spasial akan lebih membantu memberikan gambaran yang jelas dan akurat mengenai lokasi, jarak serta aksesibilitas antara lokasi daerah rawan kebakaran dengan sumberdaya pemadaman yang ada di lapangan (Andini et al, 2016).

Oleh karena itu, informasi wilayah yang menjadi konsentrasi lokasi titik api di Pulau Sumatera dan Kalimantan akan sangat membantu dalam kesiapan upaya penanggulangan bencana kebakaran hutan dan lahan yang terjadi. Tulisan ini bertujuan untuk menganalisis kerapatan titik api di Pulau Sumatera secara spasial-temporal untuk mengetahui waktu dan pusat konsentrasi titik api.

\section{METODE}

Wilayah penelitian adalah Pulau Sumatera dan Kalimantan yang merupakan pulau dengan jumlah titik api terbanyak di Indonesia.

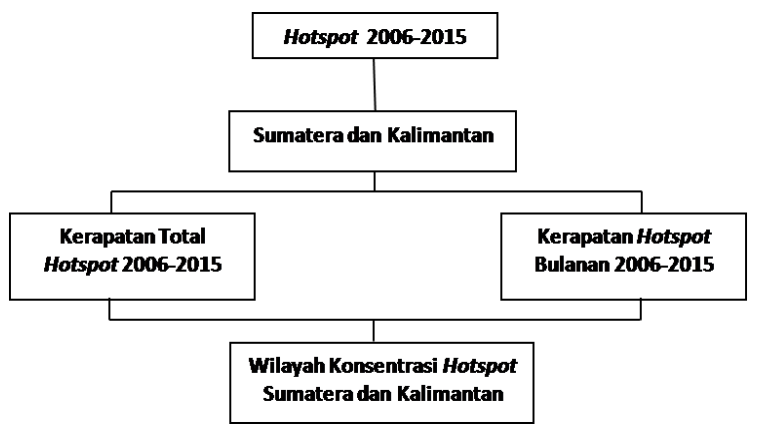

Gambar 1. Alur pikir penelitian.

Penelitian ini menggunakan data titik api dan data curah hujan. Data historis titik api periode tahun 2006-2015 menggunakan data yang terekam oleh Citra MODIS (Satelit Terra \& Aqua) dengan tingkat selang kepercayaan (confidence level) di atas $70 \%$. Hal ini bertujuan untuk membatasi data yang digunakan merupakan data titik api yang akurat, ditandai dengan pemilihan tingkat selang kepercayaan di atas $70 \%$. Analisis distribusi spatio-temporal untuk melihat kejadian dan intensitas kebakaran menggunakan data MODIS pernah dilakukan oleh Palumbo et al. (2011) di Afrika dan Vadrevu et al. (2013) di India.

Pemilihan tingkat selang kepercayaan di atas $70 \%$ didasarkan pada metode perekaman titik api oleh Satelit Terra \& Aqua, mempunyai arti bahwa suatu titik yang diidentifikasi sebagai titik api telah dilalui dan direkam secara bergantian oleh Satelit Terra maupun Satelit Aqua. Dalam identifikasi titik api, tidak jarang bahwa titik api dengan selang kepercayaan yang kurang dari $70 \%$ hanya terekam oleh salah satu dari Satelit Terra atau Aqua saja. Maka dari itu, pada tulisan ini digunakan data titik api dengan selang kepercayaan di atas $70 \%$.

Pengolahan data titik api dilakukan dengan melakukan analisis kerapatan (density analysis). Data sebaran titik api dengan tingkat selang kepercayaan di atas 70\% dari tahun 2006-2015 digunakan untuk mengetahui kerapatan titik api secara akumulasi dari tahun 2006-2015. Data tersebut didapatkan dari katalog titik api LAPAN.

Selanjutnya, dilakukan pula analisis kerapatan pada data sebaran titik api pada bulan Juni-November untuk mengetahui nilai kerapatan pada masing-masing bulan tersebut. Pemilihan bulan didasarkan pada data historis titik api yang menunjukkan bahwa pada bulan-bulan tersebut (Juni-November), jumlah titik api di Pulau Sumatera dan Kalimantan selalu mengalami peningkatan yang signifikan. Hasil dari pengolahan data dengan menggunakan analisis kerapatan akan menunjukkan wilayah mana saja 
yang menjadi wilayah dengan konsentrasi titik api paling tinggi di wilayah Sumatera dan Kalimantan. Selain itu pula, hasil dari pengolahan data titik api secara historis dapat menunjukkan pada bulan apa saja titik api di Sumatera dan Kalimantan mencapai nilai kerapatan yang paling tinggi.

Pengolahan data curah hujan menggunakan data dari JAXA TRMM dengan resolusi spasial $0.1^{\circ} \times 0.1^{\circ}$ dan resolusi temporal satu jam. Pengolahan data curah hujan bulanan dilakukan untuk melihat pola hujan bulanan di wilayah Pulau Sumatera dan Kalimantan. Hasil dari pengolahan data curah hujan bulanan tersebut akan membantu dalam melakukan analisis terhadap fenomena yang dibahas.

\section{HASIL DAN PEMBAHASAN}

\subsection{Sebaran dan Kerapatan Titik Api Selama 10 Tahun Terakhir}

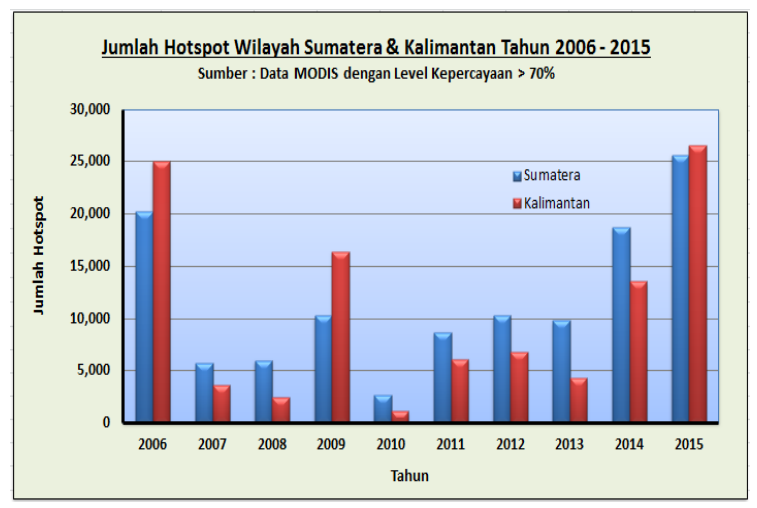

Gambar 2. Grafik jumlah titik api (hotspot) di wilayah Sumatera dan Kalimantan tahun 20062015.

Pulau Sumatera dan Kalimantan merupakan wilayah di Indonesia yang memiliki lahan gambut yang cukup luas. Lahan gambut tersebut tersebar di sepanjang pesisir timur Sumatera dan juga di bagian selatan Pulau Kalimantan. Sifat lahan gambut adalah mampu menyimpan air dalam jumlah banyak akan tetapi permukaannya cepat sekali mengering dan mudah terbakar saat musim kemarau.

Berdasarkan data Wetlands Internasional Tahun 2004/2015 dengan skala peta $1: 250.000$ diketahui luas lahan gambut di Wilayah Sumatera adalah 6,43 juta ha. Sebagian besar lahan gambut tersebut terdapat di Provinsi Riau, Jambi dan Sumatera Selatan. Di wilayah Kalimantan terdapat lahan gambut seluas 4,78 juta ha yang sebagian besar terdapat di Provinsi Kalimantan Tengah dan Kalimantan Barat.

Berdasarkan grafik jumlah titik api (hotspot) selama sepuluh tahun terakhir dari tahun 2006 hingga tahun 2015 seperti yang direpresentasikan pada Gambar 2. dapat diketahui bahwa jumlah titik api di Indonesia untuk tiap tahunnya selama sepuluh tahun terakhir rata-rata relatif cukup tinggi hingga diatas 10.000 titik per tahun.

Berdasarkan Gambar 2 tersebut juga dapat diketahui bahwa titik api di wilayah Sumatera dan Kalimantan pada tahun 2006 dan 2015 relatif cukup tinggi hingga diatas 50.000 titik api. Hal ini disebabkan karena pada tahun 2006 dan 2015 terjadi El Nino yang menyebabkan berkurangnya curah hujan di sebagain besar wilayah Indonesia. Penurunan curah hujan di Indonesia akibat El-Nino paling kuat terdapat di daerah Sumatra bagian selatan, Jawa, Kalimantan, Sulawesi Selatan, Sulawesi Tenggara, Sulawesi Utara, Maluku Utara, serta Irian Jaya yang berlangsung pada bulan September-Oktober-Nopember (Mulyana, 2002).

Pada tahun El Nino, musim kemarau lebih panjang dengan jumlah curah hujan yang lebih rendah. Nilai SOI pada tahun 2006 dan 2015 yang sangat rendah (Tabel 1) terutama pada bulan-bulan musim kemarau menyebabkan minimnya curah hujan di sebagian besar wilayah Indonesia. Kondisi tersebut menyebabkan semakin keringnya lahan gambut dan sangat mudah terbakar, sehingga titik api di tahun 2006 dan 2015 tersebut relatif sangat tinggi dibandingkan tahun-tahun yang lainnya. Berdasarkan peta analisis sebaran dan kerapatan titik api di wilayah Sumatera dan Kalimantan yang direpresentasikan pada

Tabel 1. Timeline Fenomena El Nino beserta Nilai SOI dari Tahun 2006-2015.

\begin{tabular}{|c|c|c|c|c|c|c|c|c|c|c|c|c|}
\hline Tahun & Jan & Feb & Mar & Apr & May & Jun & Jul & Aug & Sep & Oct & Nov & Dec \\
\hline 2015 & -7.8 & 0.6 & -11.2 & -3.8 & -13.7 & -12 & -14.7 & -19.8 & -17.8 & -20.2 & -5.3 & -9.1 \\
\hline 2014 & 12.2 & -1.3 & -13.3 & 8.6 & 4.4 & -1.5 & -3 & -11.4 & -7.6 & -8 & -10 & -5.5 \\
\hline 2013 & -1.1 & -3.6 & 10.5 & 0.3 & 8.4 & 13.9 & 8.1 & -0.5 & 3.9 & -1.9 & 9.2 & 0.6 \\
\hline 2012 & 9.4 & 2.5 & 2.9 & -7.1 & -2.7 & -10.4 & -1.7 & -5 & 2.6 & 2.4 & 3.9 & -6 \\
\hline 2011 & 19.9 & 22.3 & 21.4 & 25.1 & 2.1 & 0.2 & 10.7 & 2.1 & 11.7 & 7.3 & 13.8 & 23 \\
\hline 2010 & -10.1 & -14.5 & -10.6 & 15.2 & 10 & 1.8 & 20.5 & 18.8 & 24.9 & 18.3 & 16.4 & 27.1 \\
\hline 2009 & 9.4 & 14.8 & 0.2 & 8.6 & -7.4 & -2.3 & 1.6 & -5 & 3.9 & -14.7 & -6 & -7 \\
\hline 2008 & 14.1 & 21.3 & 12.2 & 4.5 & -3.5 & 4.2 & 2.2 & 9.1 & 13.5 & 13.4 & 17.1 & 13.3 \\
\hline 2007 & -7.8 & -2.7 & -1.4 & -3 & -2.7 & 5 & -5 & 2.7 & 1.4 & 5.4 & 9.2 & 14.4 \\
\hline 2006 & 12.7 & 0.1 & 13.8 & 14.4 & -9.8 & -6.3 & -7.6 & -15.9 & -5.8 & -16 & -1.4 & -3.5 \\
\hline
\end{tabular}

(Sumber : Australian Government Bureau of Meteorology). 
Gambar 3 dapat diketahui bahwa selama sepuluh tahun terakhir konsentrasi titik api di wilayah Sumatera terdapat di Provinsi Sumatera Selatan dan Provinsi Riau dengan tingkat konsentrasi/kerapatan yang hampir sama. Konsentrasi titik api yang tinggi di Pulau Kalimantan terdapat di Provinsi Kalimantan Tengah dan Provinsi Kalimantan Barat.

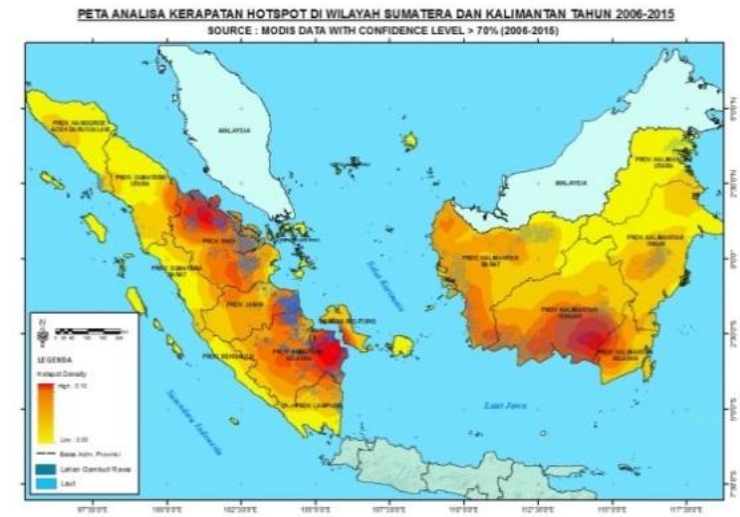

Gambar 3. Peta analisis sebaran dan kerapatan titik api di wilayah Sumatera dan Kalimantan tahun 2006-2015.

Berdasarkan gambar 3 tersebut, dapat diketahui bahwa konsentrasi titik api tertinggi sebagian besar berada di daerah lahan gambut. Sifat permukaan lahan gambut yang mudah kering dalam beberapa hari jika tidak terjadi hujan akan menjadikan daerah tersebut rawan terbakar saat memasuki musim kering. Selain itu, pembukaan lahan secara besar-besaran untuk konversi ke perkebunan selama 10 tahun terakhir juga menjadi salah satu penyebab konsentrasi keberadaan titik api di wilayah Sumatera dan Kalimantan sebagian besar berada pada daerah lahan gambut tersebut.

\subsection{Sebaran dan Kerapatan Titik Api Bulanan Selama 10 Tahun Terakhir}

Untuk mengetahui sebaran dan konsentrasi titik api secara spasial dan temporal dibuat grafik jumlah titik api bulanan (Gambar 4) dan peta sebaran dan kerapatan titik api bulanan (Gambar 5) di wilayah Sumatera dan Kalimantan selama sepuluh tahun terakhir.

Berdasarkan Gambar 4 dapat diketahui bahwa secara umum selama sepuluh tahun terakhir titik api di Wilayah Sumatera dan Kalimantan mulai muncul sejak bulan Febuari dan bulan Maret, menurun lagi pada bulan April dan bulan Mei, dan mulai terus meningkat dari bulan Juni hingga puncaknya di bulan September, sedikit menurun pada kondisi puncaknya pada bulan Oktober dan jumlah titik api tersebut menurun secara drastis pada bulan November, Desember dan Januari di tahun berikutnya. Fluktuasi jumlah titik api tersebut tidak lepas dari pola hujan di wilayah Pulau Sumatera dan Kalimantan.

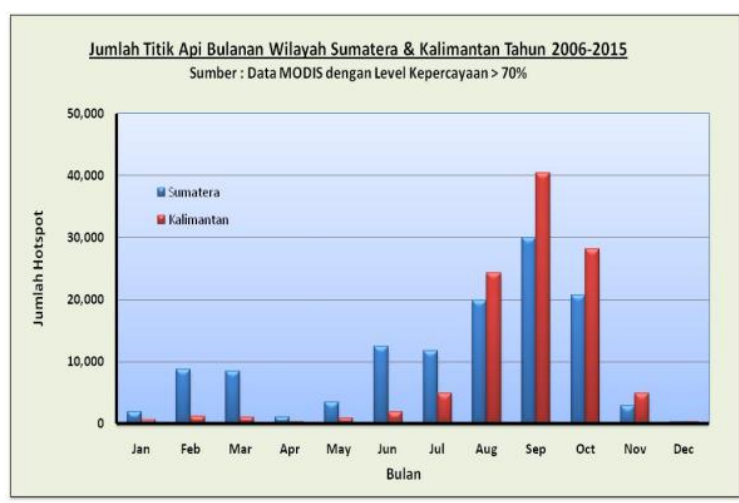

Gambar 4. Grafik jumlah titik api bulanan di wilayah Sumatera dan Kalimantan tahun 20062015.

Secara umum, provinsi di Sumatera dan Kalimantan mempunyai dua (2) puncak musim hujan yang terjadi pada bulan April-Mei dan Desember-Januari. Maka dari itu, fluktuasi hotspot akan mengikuti pula pola curah hujan bulanan di masing-masing provinsi.

Berdasarkan Gambar 5 dapat diketahui bahwa konsentrasi titik api pada bulan Januari hingga Juli sebagian besar terdapat di wilayah Sumatera khususnya di Provinsi Riau. Konsentrasi titik api di wilayah Riau tersebut relatif rendah di bulan Januari, pada bulan Februari dan Maret konsentrasi titik api di Provinsi Riau tersebut relatif meningkat dan menurun kembali pada bulan April dan bulan Mei.

Akan tetapi pada bulan Juni dan bulan Juli konsentrasi titik api di Wilayah Sumatera khususnya di Provinsi Riau relatif meningkat kembali, dimana konsentrasi titik api tertinggi pada bulan Juni dan Juli berada di sekitar Kota Dumai. Sedangkan di wilayah Kalimantan, konsentrasi titik api mulai mengalami peningkatan pada bulan Juli khusususnya di Provinsi Kalimantan Tengah dan Kalimantan Barat.

Perubahan konsentrasi titik api tersebut dipengaruhi oleh distribusi curah hujan bulanan. Peningkatan konsentrasi titik api pada periode Juli-Oktober merupakan pengaruh dari minimnya curah hujan bulanan di sebagian wilayah Sumatera dan Kalimantan. Pada bulan Agustus konsentrasi titik api cukup merata baik di Wilayah Sumatera maupun Kalimantan dengan tingkat kerapatan/konsentrasi titik api yang tinggi. Pada bulan Agustus, konsentrasi titik api di wilayah Sumatera berada di Provinsi Riau, Sumatera Selatan dan Jambi, sedangkan di wilayah Kalimantan konsentrasi titik api berada di wilayah Provinsi Kalimantan Tengah dan Kalimantan Barat. 
Berdasarkan visualisasi data titik api sepuluh tahun tersebut (2006-2015), dapat diketahui bahwa pada bulan September merupakan puncak dari keberadaan titik api baik di wilayah Sumatera maupun di Kalimantan, dimana jika di bulan-bulan sebelumnya di wilayah Sumatera konsentrasi titik api cenderung di Provinsi Riau, akan tetapi pada bulan September hingga Oktober konsentrasi titik api di wilayah Sumatera cenderung di Provinsi Sumatera Selatan dengan tingkat kerapatan/konsentrasi titik api yang sangat tinggi.

Sedangkan di wilayah Kalimantan pada bulan September hingga Oktober konsentrasi titik api cenderung di Provinsi Kalimantan Tengah juga dengan tingkat kerapatan/konsentrasi titik api yang sangat tinggi. Pada bulan November dan Desember seiring dengan datangnya musim penghujan di sebagian besar wilayah Indonesia, keberadaan titik api di Sumatera dan Kalimantan jauh menurun dibandingkan bulan-bulan sebelumnya.

\subsection{Rata-rata Curah Hujan Bulanan}

Data distribusi spasial rata-rata curah hujan bulanan direpresentasikan pada Gambar 6 dan 7. Gambar 6 menyajikan grafik yang menunjukkan pola hujan di wilayah Sumatera dan Kalimantan. Berdasarkan data TRMM yang telah diolah, maka dapat diamati bahwa curah hujan di wilayah Sumatera dan Kalimantan akan mencapai nilai minimum pada periode JuliOktober. Hal ini mempunyai pola yang

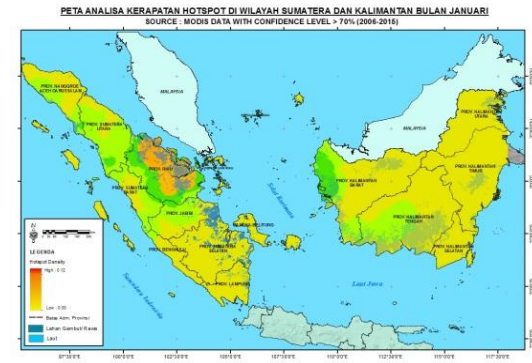

Januari

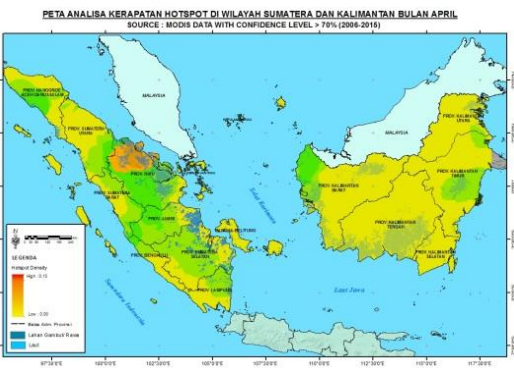

April

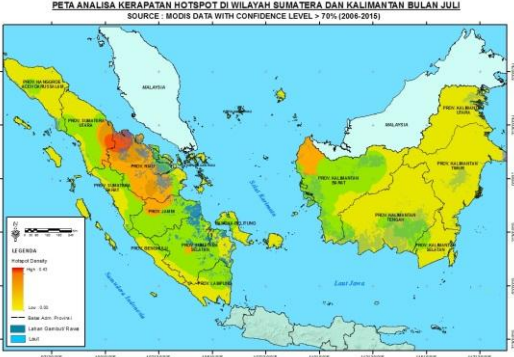

Juli

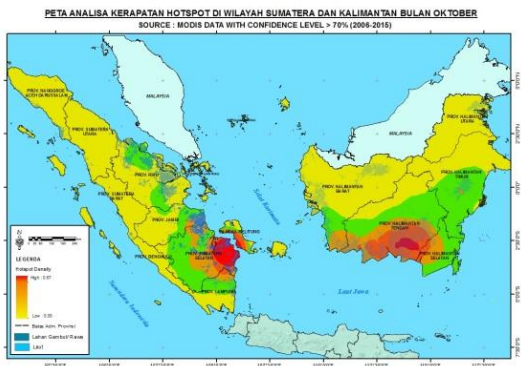

Oktober

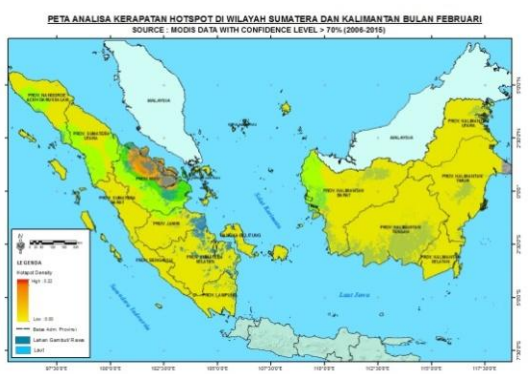

Februari

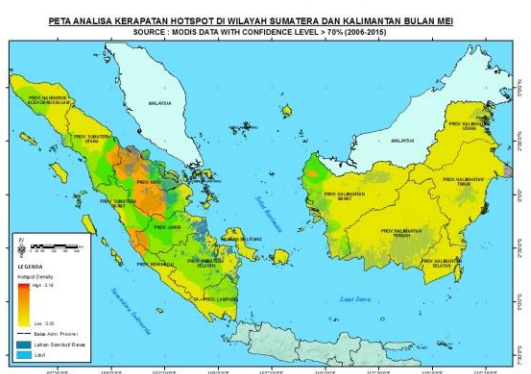

Mei

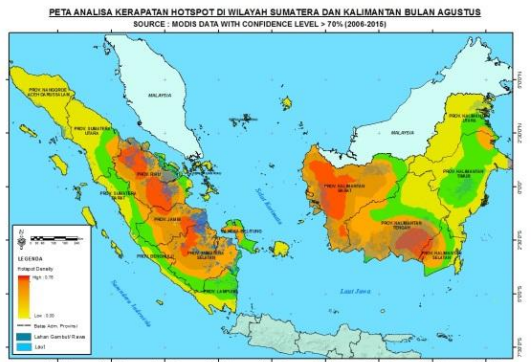

Agustus

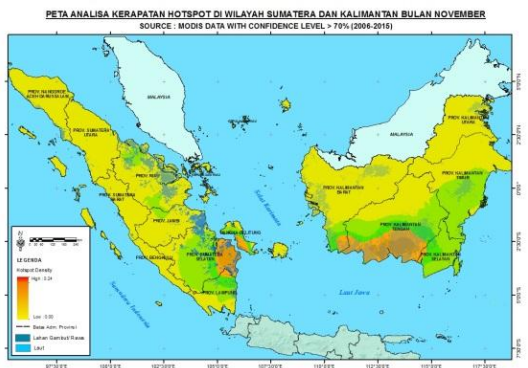

November

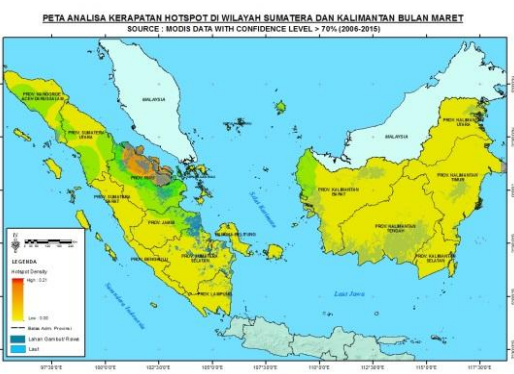

Maret

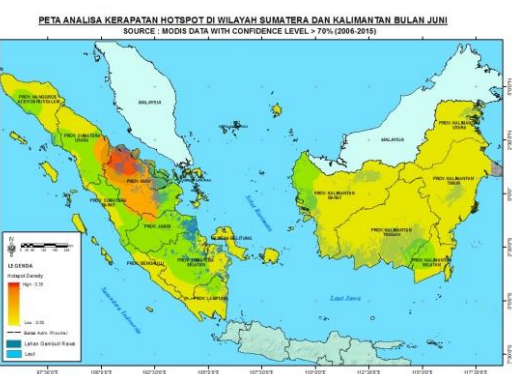

Juni

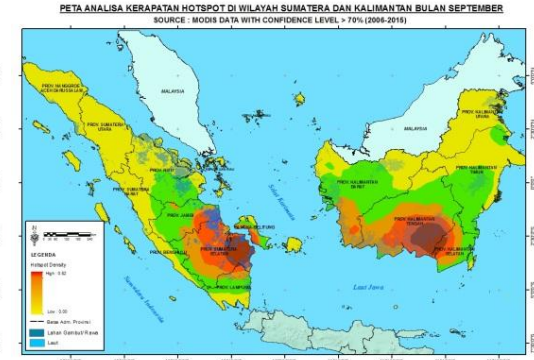

September

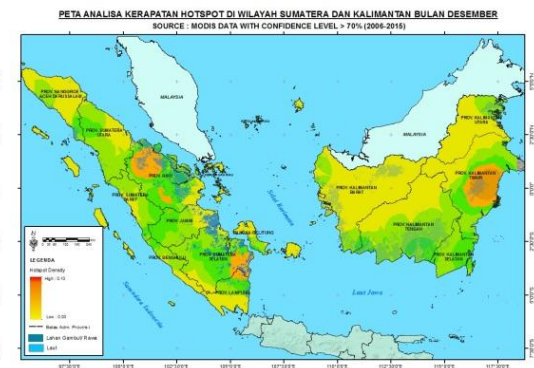

Desember

Gambar 5. Peta analisis sebaran dan kerapatan titik api bulanan (Januari-Desember) di wilayah Sumatera dan Kalimantan tahun 2006-2015. 
berkebalikan dengan jumlah titik api di wilayah Sumatera dan Kalimantan. Sebelumnya pada Gambar 4 telah dijelaskan bahwa titik api di wilayah Sumatera dan Kalimantan akan mencapai puncaknya pada periode yang sama. Kondisi hujan yang mencapai nilai terendahnya akan memicu banyaknya titik api yang muncul di wilayah Sumatera dan Kalimantan.

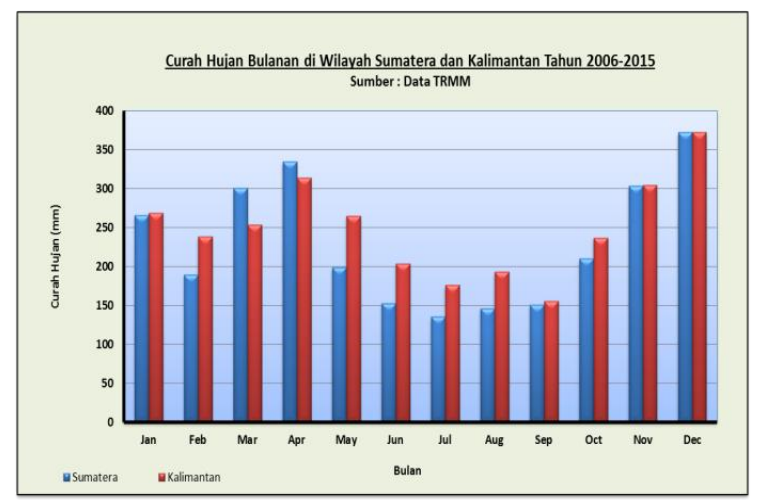

Gambar 6. Grafik curah hujan bulanan di wilayah Sumatera dan Kalimantan tahun 2006-2015.

Berdasarkan visualisasi distribusi spasial rata-rata curah hujan, dapat diketahui bahwa jumlah, sebaran dan konsentrasi/kerapatan titik api tiap bulannnya di wilayah Sumatera dan Kalimantan juga memiliki korelasi dengan ratarata curah hujan bulanan di wilayah tersebut.

CURAH HUJAN RATA-RATA BULAN JUNI (2009-2015)
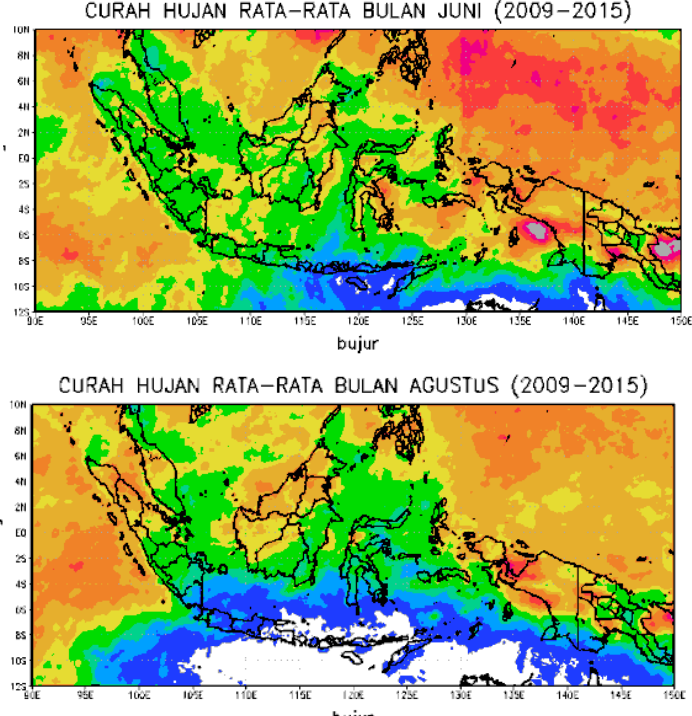

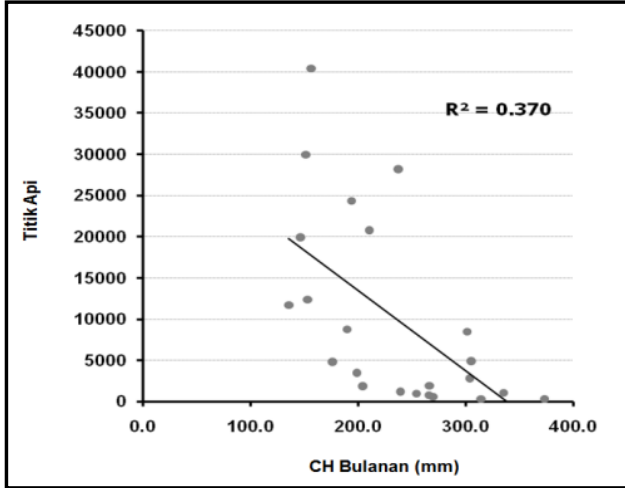

Gambar 7. Diagram scatter plot yang menunjukkan korelasi jumlah titik api dan curah hujan bulanan di Sumatera dan Kalimantan.

Gambar 7 menunjukkan diagram tebar yang menggambarkan korelasi antara jumlah titik api dan curah hujan bulanan di wilayah Sumatera dan Kalimantan. Nilai korelasi $\left(R^{2}\right)$ yaitu sebesar 0,37 menandakan korelasi yang cukup berkaitan antara curah hujan bulanan terhadap jumlah titik api di Sumatera dan Kalimantan. Pola yang terbentuk yaitu hubungan negatif, di mana saat curah hujan bulanan berangsur naik maka jumlah titik api akan berangsur turun.

Gambar 8 merepresentasikan curah hujan bulanan pada saat bulan-bulan kering di mana jumlah dan konsentrasi titik api mencapai puncaknya.
CURAH HUJAN RATA-RATA BULAN JULI (2009-2015)

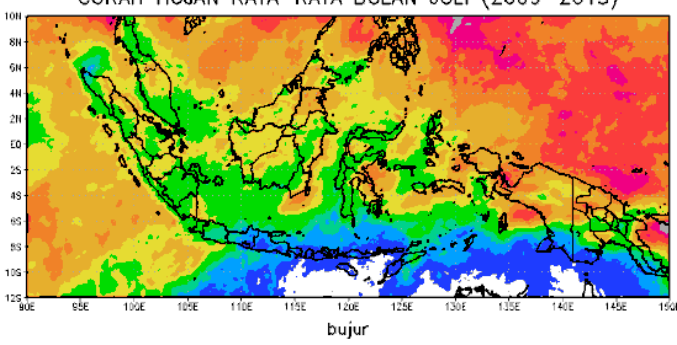

CURAH HUJAN RATA-RATA BULAN SEPTEMBER (2009-2015)

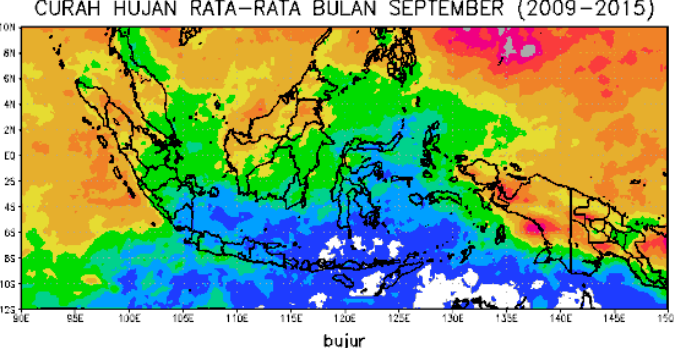

CURAH HUJAN RATA-RATA BULAN OKTOBER (2009-2015)
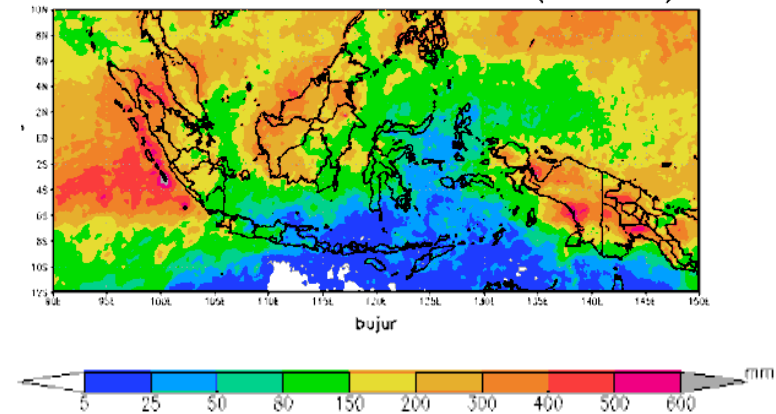

Gambar 8. Peta rata-rata curah hujan bulanan Juni-Oktober wilayah Indonesia tahun 2009-2015. 
Jumlah titik api di wilayah Sumatera dan Kalimantan mulai meningkat secara signifikan mulai bulan Juni dan puncaknya di bulan September, sebanding dengan penurunan ratarata curah hujan bulanan di wilayah tersebut. Rata-rata curah hujan pada bulan Juni di sebagian besar wilayah Sumatera dan Kalimantan relatif kecil sekitar $80-150 \mathrm{~mm}$ jika dibandingkan dengan bulan-bulan sebelumnya, curah hujan tersebut semakin menurun dan puncak penurunannya di bulan September yaitu sekitar 25-150 mm, hal ini sama seperti puncak keberadaan titik api di wilayah Sumatera dan Kalimantan. Pada bulan Oktober curah hujan di wilayah Sumatera dan Kalimantan sudah relatif meningkat walaupun belum signifikan sehingga keberadaan titik api juga masih dalam jumlah yang relatif banyak. Sedangkan pada bulan November hingga Desember curah hujan meningkat secara signifikan di sebagian besar wilayah Sumatera dan Kalimantan sehingga keberadaan titik api di bulan ini relatif sangat sedikit.

\section{KESIMPULAN}

Berdasarkan pengolahan data titik api historis pada tahun 2006-2015, menunjukkan bahwa Provinsi Riau dan Sumatera Selatan merupakan wilayah dengan kerapatan titik api paling tinggi selama 10 tahun terakhir di Pulau Sumatera. Sementara Provinsi Kalimantan Tengah dan Kalimantan Barat merupakan wilayah dengan kerapatan titik api yang tinggi di Pulau Kalimantan. Hasil analisis sebaran titik api secara bulanan menunjukkan bahwa jumlah dan kerapatan titik api di Pulau Sumatera dan Kalimantan akan mencapai puncaknya pada bulan September.

Pola kerapatan titik api dan kaitannya dengan curah hujan bulanan, bisa menjadi gambaran dalam penyusunan strategi penanggulangan bencana kebakaran hutan dan lahan di Indonesia. Persiapan penanggulangan bencana asap akibat karhutla seperti Teknologi Modifikasi Cuaca, akan lebih baik dipersiapkan sebelum kondisi kering mencapai puncaknya.

\section{DAFTAR PUSTAKA}

Albar, I., Jaya, N.S., Saharjo, B.H., Kuncahyo, B. (2016). Spatio-Temporal Typology of Land and Forest Fire in Sumatra. Indonesian Journal of Electrical Engineering and Computer Science, 4(1), 83-90. doi: 10.11591/ljeecs.V4.I1.Pp83-90

Andini, N., Zaitunah, A., Samsuri. (2016). Model Spasial Tingkat Kerawanan Kebakaran Hutan dan Lahan di Kabupaten Rokan Hilir. Peronema Forestry Science Journal, 5(2), 91-100.
Barber, C.V., Schweithelm, J. (2000). Trial by Fire: Forest Fires and Forestry Policy in Indonesias Era of Crisis and Reform. World Resources Institute. Washington. $76 \mathrm{p}$.

Cahyono, S.A., Warsito, S.P., Andayani, W., Darwanto, D.H. (2015). Faktor-Faktor yang Mempengarui Kebakaran Hutan di Indonesia dan Implikasi Kebijakannya. Jurnal Sylva Lestari, 3(1), 103-112.

Chokkalingam, U., Suyanto, Permana, R.P., Kurniawan, I., Mannes, J., Darmawan, A., Khususyiah, N., Susanto, R.H. (2007). Community Fire Use, Resource Change, and Livelihood Impacts: The Downward Spiral in The Wetlands of Southern Sumatra. Mitigation and Adaptation Strategies for Global Change, 12(1), 75100. doi: 10.1007/s11027-006-9038-5

Gellert, P.K. (1998). A Brief History and Analysis of Indonesia's Forest Fire Crisis. Cornell's Journal Indonesia, 65, 63-85. doi: $10.2307 / 3351404$

Herawati, H., Santoso, H. (2011). Tropical Forest Susceptibility and Risk of Fire Under Changing Climate: A Review of Fire Nature, Policy and Institutions in Indonesia. Forest Policy and Economics, 13(4), 227-233. doi: 10.1016/j.forpol.2011.02.006

Levine, J.S. (1999). The 1997 Fires in Kalimantan and Sumatra, Indonesia: Gaseous and Particulate Emissions. Geophysical Research Letters, 26(7), 815818. doi: 10.1029/1999GL900067

Miettinen, J., Shi, C., Liew, S.C. (2011). Influence of Peatland and Land Cover Distribution on Fire Regimes in Insular Southeast Asia. Regional Environmental Change, 11(1), 191-201. doi: 10.1007/s10113-010-0131-7

Mulyana, E. (2002). Pengaruh Dipole Mode Terhadap Curah Hujan di Indonesia. Jurnal Sains \& Teknologi Modifikasi Cuaca, 3(1), $39-43$.

Page, S.E., Siegert, F., O.Rieley, J., Boehm, H.D.V., Jaya, A., Limin, S. (2002). The Amount of Carbon Released from Peat and Forest Fires in Indonesia During 1997. Nature, 420, 61-65. doi:10.1038/Nature01131

Palumbo, I., Gregoire, J.M., Simonetti, D., Punga, M. (2011). Spatio-Temporal Distribution of Fire Activity in Protected Areas of SubSaharan Africa Derived from MODIS Data. Procedia Environmental Sciences, 7, 2631. doi: 10.1016/j.proenv.2011.07.006

Rasyid, F. (2014). Permasalahan dan Dampak Kebakaran Hutan. Jurnal Lingkar Widyaiswara, 1(4), 47-59.

Samsuri, I.N.S., Syaufina, L. (2008). Model Spasial Tingkat Kerawanan Kebakaran 
Hutan dan Lahan (Studi Kasus di Wilayah Propinsi Kalimantan Tengah). Foresta Indonesian Journal of Forestry, 1(1), 1218.

Vadrevu, K.P., Csiszar, I., Ellicott, E., Giglio, L., Badarinath K.V.S., Vermote, E., Justice, C.
(2013). Hotspot Analysis of Vegetation Fires and Intensity in The Indian Region. IEEE Journal of Selected Topics in Applied Earth Observations and Remote Sensing, 6(1), 224-238. doi: 10.1109/Jstars.2012.2210699 